\title{
Por outras histórias: entre Walter Benjamin e Jorge Luis Borges
}

\author{
Marília Nogueira Carvalho*
}

Este artigo pretende investigar o conceito de história de Walter Benjamin, a partir da idéia do questionamento da noção de verdade no texto histórico e ficcional para sugerir o esquecimento como interrupção na linearidade narrativa e, consequentemente, como mote para construção de outras histórias. O aporte crítico e teórico sobre Walter Benjamin encontra-se nos escritos de Jeanne Marie Gagnebin e Michael Löwi. O artigo aponta, ainda, para alguma relação entre o trabalho do historiador e a tarefa do tradutor.

Palavras-chave: Walter Benjamin. Jorge Luis Borges. História. Verdade. Esquecimento.

This essay intends to investigate Walter Benjamin's concept of history by questioning the notion of thruth, in both historical and literary text, in order to suggest the idea of forgetfulness as an interruption in the linear narrative, and, thus, as a way to create other histories. The theoretical basis on Walter Benjamin relies on Jeanne Marie Gagnebin's and Michael Löwi's writings. This essay also comments on the relation between the historian's work and the translator's task.

Key words: Walter Benjamin. Jorge Luis Borges. History. Truth. Forgetfulness.

\begin{abstract}
Os fatos posteriores deformaram até o inextrincável a lembrança de nossas primeiras jornadas.

No tempo real, na história, toda vez que um homem se encontra perante diversas alternativas, opta por uma e elimina e perde as outras; não é assim no tempo ambíguo da arte, que se assemelha ao da esperança e do esquecimento. Hamlet, em tal tempo, é são da cabeça e é doido. Nas trevas da torre da Fome, Ugolino devora e não devora os corpos dos filhos amados, e esta imprecisão ondulante, esta incerteza é a estranha matéria de que ele é feito. Assim, em duas agonias possíveis, foi sonhado por Dante, e assim o sonham as gerações vindouras.
\end{abstract}

Jorge Luis Borges

Em A rosa profunda (1975), de Jorge Luis Borges, há dois poemas sobre Proteu, "Proteu" e "A outra versão de Proteu", em que Borges parece novamente aludir a esse tempo próximo ao da esperança e do esquecimento. Proteu tenta se livrar do fardo de saber o futuro, ocultando o que sabe e contando outra história. É sabido da angústia daqueles que conhecem o futuro, e o quanto esses profetas tentam esconder o que sabem, porque conhecê-lo é retirar dele qualquer outro possível, quaisquer outras possibilidades, ou ainda, sucumbir aos diversos caminhos traçados a partir de diferentes escolhas a um único destino.

\footnotetext{
* Marília Nogueira Carvalho (Fortaleza, 1982) é mestre em Estudos Literários pela UFMG, com pesquisa sobre espaço narrativo em alguns contos de Jorge Luís Borges (Bolsista da CAPES). Organizou o livro, A Vida ao rés do chão: artes de Bispo do Rosário (7Letras, 2007 ), com Fernanda Coutinho e Renata Moreira.
} 
Não é difícil lembrar o cego Tirésias que escondeu o quanto pôde a verdade de Édipo, em Édipo-rei, e a força do seu destino traçado não cedeu à possibilidade de outro caminho, porque aquele era um tempo em que se vivia sob a sombra dos oráculos, em que não era possível construir a outra história ou mesmo fugir da mesma.

E Borges confere ao Proteu a outra possibilidade ao dizer que ele "preferia ocultar o que sabia / e entretecer uns oráculos díspares"1, porque sabe-se também que "a memória definha". A Proteu não é dado o conhecimento apenas do futuro, mas do passado e do presente, o que lhe possibilita a tessitura da trama. E Borges também tece quando dedica a Proteu dois poemas, como se Proteu contasse duas histórias, ou se a história de Proteu comportasse duas versões.

\section{Proteu}

Antes que os remeiros de Odisseu Fatigassem os mares cor de vinho, As inapreensíveis formas adivinho Daquele deus cujo nome foi Proteu. Um pastor dos rebanhos desses mares Que possuía o dom da profecia preferia ocultar o que sabia e entretecer uns oráculos dispares. Urgido pela gente, assumia

A forma de um leão, de uma fogueira Ou de árvore que ensombra a ribeira Ou de água que na água se perdia. Com Proteu, o egípcio, não te assombres, tu, que é um e ao mesmo tempo muitos homens.

\section{Outra versão de Proteu}

Habitante de areias receosas, Meio deus, meio fera marinha, Ignorou a memória que, definha Sobre o ontem e as perdidas coisas. Outro tormento padeceu Proteu Não menos cruel, saber o que encerra O futuro: uma porta que se cessa Para sempre o troiano e o aqueu. Capturado, tomava a inapreensível Forma do furacão ou da fogueira Ou do tigre de ouro ou da pantera Ou de água que na água é invisível. Tu também estás feito de inconstantes Ontens e amanhãs. No entanto, antes... ${ }^{2}$

\footnotetext{
${ }^{1}$ BORGES. Obras completas, 1999c, p. 109.

${ }^{2}$ BORGES. Obras completas, 1999c, p. 109 e 110.
} 
Em "Proteu", a primeira imagem construída é a dos remeiros de Odisseu diante das inapreensíveis formas deste, que "urgido pela gente, assumia / a forma de um leão, de uma fogueira / ou de árvore que ensombra a ribeira / ou de água que na água se perdia”. Proteu é pano sem fundo, pois figura a imagem do inapreensível a fim de não revelar o que sabe, que pra ele era um tormento como diz o segundo poema, "outro tormento padeceu Proteu / não menos cruel, saber o que encerra / o futuro: uma porta que se cessa / para sempre o troiano e o aqueu.". O futuro como uma porta cerrada é um futuro sem possibilidades, sem outras histórias, ou ainda guiado pelos oráculos, pelas profecias. Proteu é o deus da profecia, mas no poema, ele "preferia ocultar o que sabia/ e entretecer alguns oráculos díspares”, ele que é um e também muitos homens, como Hamlet que é são e louco ao mesmo tempo.

No segundo poema, Proteu logo aparece sob essa inconstância, como "meio deus, meio fera marinha", e o poema termina conferindo essa mesma inconstância no leitor, “tu também estás feito de inconstantes / ontens e amanhãs. No entanto antes...". Essa última frase pode estar aí para não quebrar a rima de um soneto à maneira de Shakespeare ${ }^{3}$ e/ou ainda para propor o fato de que o que antes havia foi esquecido e/ou será preenchido pelo leitor. ${ }^{4}$ Há ainda nesse poema a constatação de que a memória definha, se esvaece, e do quanto pesa ao profeta saber sobre o futuro. Como já foi dito, o conhecimento do futuro - sob tal perspectiva - é a certeza de que o amanhã não mudará, mesmo que se escolha outro caminho ${ }^{5}$, pois o futuro é uma porta cerrada.

O que Borges não ressalta em seus poemas é o fato de que Proteu se esquiva de revelar o que lhe é perguntado também através da linguagem. Proteu é descrito na Odisséia como "o infalível marinho ancião (...) / (...) das paragens egípcias, / que sabe todos os fundos do mar e é vassalo do divo Posido"6. Ele é o deus, na mitologia grega, que possui o dom da profecia e o da transformação. A ele foi concedido o conhecimento do passado, presente e futuro, mas quando era questionado, Proteu se esquivava transformando-se em tudo o que bem lhe conviesse: leão, dragão, javali, água, árvore ou fogo. Mas quem conhecia seus ardis, sabia que devia aprisioná-lo sob

\footnotetext{
${ }^{3} 14$ versos e rimas entrelaçadas finalizando num dístico.

${ }^{4}$ Vale lembrar que Borges muito apreciou o papel do leitor. Ver: "Pierre Menard, autor de Quixote" e "Kafka e seus precursores".

${ }^{5}$ Édipo, em Édipo-rei, é jogado na floresta porque seu pai tem medo de sua profecia. Mas mesmo assim, a profecia acaba por realizar-se.

${ }^{6}$ HOMERO. Odisséia, 2001, p.82.
} 
todas essas formas até que ele cansasse e tentasse de outro jeito, dessa vez com a linguagem, escusar-se da pergunta com outras perguntas. Somente depois disso acontecido Proteu revelava o que sabia.

A partir dessa questão do inacessível em Proteu, podemos esboçar alguma relação entre o trabalho do historiador e do tradutor em Benjamin. Dois livros que foram publicados simultaneamente, um no Brasil e outro nos Estados Unidos, Walter Benjamin: tradução e melancolia, de Susana Kampf Lages e Reading Borges after Benjamin, de Kate Jenckes, nos foram caros para essa conexão. Podemos inferir dessas leituras e do ensaio benjaminiano, "A tarefa do tradutor", que as teorias tradicionais sobre a figura do historiador e do tradutor tinham por pressuposto a busca pela verdade, no caso do historiador, e a busca pela correspondência com o original, no caso do tradutor, ambas inalcançáveis; e que hoje, as teorias sobre o tradutor e o historiador já apontam para o fato de que seus objetivos não devem se fundar nessa esperança, na procura dessa similitude com a verdade e com o texto de partida ("original"), pois, para Benjamin, isso cai por terra quando nos deparamos com a impossibilidade de uma teoria da imitação, no sentido de semelhança com o original. Em “A doutrina das semelhanças", Benjamin discute justamente sobre essa capacidade do homem de produzir semelhanças, de agir segundo a lei da semelhança devido à faculdade mimética que lhe é inerente. Discute ainda o fato de a linguagem sofrer certa influência dessa faculdade mimética, pois seu funcionamento se dá com a produção de semelhanças extra-sensíveis que estabelecem a ligação entre o falado e o escrito.

Nesse mesmo texto, Benjamin diz que "se ordenarmos várias palavras das diferentes línguas, com a mesma significação, em torno desse significado, como seu centro, pode-se verificar como todas essas palavras, que não tem entre si a menor semelhança são semelhantes ao significado situado no centro." ${ }^{, 7}$ Esse fragmento nos leva a pensar em uma correspondência que pode haver entre as línguas no que diz respeito ao significado e a comunicação $^{8}$, mas não é sobre isso que trata a tradução. Para

\footnotetext{
${ }^{7}$ BENJAMIN. Magia e técnica, arte e política, 1994, p. 111.

${ }^{8}$ Sobre essa questão, temos em "A tarefa do tradutor": "é necessário distinguir, nessa intencionalidade, o que se quer dizer (das Gemeinte) do modo como se quer dizer (die Art des Meinens). Nas palavras "Brot" e "pain" o que se quer dizer é o mesmo, mas não o modo de o querer dizer. É devido a esse modo de querer dizer que ambas as palavras significam coisas diferentes para um Alemão e um Francês, que elas não são permutáveis, que, em última análise, tendem para a exclusão mútua; e é por via do que querem dizer que elas, tomadas em absoluto, significam algo que é o mesmo e idêntico." (BENJAMIN apud BRANCO (org.). A tarefa do tradutor, de Walter Benjamin, 2008, p.88). Borges
} 
Benjamin, a tradução não deve comunicar sentido algum do texto de partida, nem deve se dirigir ou servir ao leitor, visto que sua essência não é a comunicação nem a informação. Ela tem por finalidade expor uma relação de complementaridade entre as línguas, e não substituir um sentido pelo outro, ou transportar de um sentido a outro.

Márcio Seligmann-Silva observa que a ausência dessa instância comunicativa na tradução a aproxima do Texto Sagrado, que é visto como o que mais se distancia desse sentido comunicacional devido à pluralidade de suas interpretações. ${ }^{9}$ Benjamin fala em "língua pura" ou "divina", a partir da qual são derivadas as línguas humanas. Segundo o autor alemão a tradução resgata algo da "língua pura" que o texto de partida não tem, propondo, assim, que a tradução seja uma recriação poética, que consiga libertar o texto de origem das amarras figurativas ou representativas da linguagem, que a tradução o toque em apenas um ponto, como uma tangente toca a circunferência, para que a partir daí ela siga seu curso de infinitas possibilidades.

Em “A tarefa do tradutor", Benjamin cita Rudolf Pannwitz para dizer de uma intervenção que deve haver da língua estrangeira na original. E o que sugerimos é uma semelhança entre essa intervenção e as intervenções do presente no passado. Assim como o presente pode modificar o passado, uma tradução também pode transformar o texto de partida, da mesma forma que a figura do precursor para Borges modifica o texto lido.

Podemos ainda apontar outra semelhança, desta vez, entre o historiador benjaminiano e o precursor de Borges. Vimos que o historiador de Benjamin não deve buscar qualquer explicação do presente no passado, ou vice-e-versa, nem tentar entender um pelo outro, mas deve, sim, buscar aproximá-los por semelhanças ou diferenças, a fim de provocar o embate entre os tempos para, quem sabe, poder surgir, assim, a imagem dialética. Isso o fará modificar o passado a partir do presente. E o que é a figura do precursor em Borges senão aquele leitor que, no presente, modifica a leitura de uma obra passada? O precursor é aquele que re-lê, que re-vê, que re-discute, que re-aponta

também descreve de forma semelhante em "O idioma analítico de John Wilkins" ao dizer que a palavra "luna" pode ser mais ou menos expressiva que a palavra "moon", explicando o fato de que o monossílabo "moon" talvez expresse melhor um objeto muito simples que a palavra dissílaba "luna". No entanto, ele diz: "excetuando as palavras compostas e as derivações, todos os idiomas do mundo [...] são igualmente inexpressivos". (BORGES. Obras completas, 1999b, p. 92-93). A partir dessas falas de um e de outro podemos afirmar que enquanto Benjamin se preocupa em diferenciar a linguagem em termos comunicacionais e formais, Borges atenta para o caráter arbitrário da língua, mas ambos pensam a linguagem além da comunicação.

9 “A tora", diz Seligman, é vista pela tradição judaica como um texto infinitamente prenhe de sentido e que, justamente devido a esse paroxismo do semântico, não oferece a possibilidade de uma interpretação fechada." SELIGMAN-SILVA (org.). Leituras de Walter Benjamin, 2007, p. 30. 
e que re-escreve outras fissuras desse texto literário que já foi tão lido, tão citado e tão questionado. É aquele que possibilita o desenvolvimento de uma nova questão para aquele texto, ou apresenta sob outro prisma aquela mesma questão já tão bem tratada. Acreditamos que essa função do leitor borgeano com o texto lido assemelha-se à função do historiador benjaminiano e sua relação com a verdade.

Ao aproximar Borges e a história, ao discutir a possibilidade de um imbricação entre o discurso histórico e o literário a fim de propor alguma contribuição entre um e outro, Julio Pimentel Pinto, historiador, discorre sobre essa questão da verdade e aponta o quanto a Nova História tem se alimentado de outros discursos, e como alguns historiadores, Hayden White ${ }^{10}$ e Dominick LaCapra ${ }^{11}$, discutem a verdade em conjunção com a imaginação:

\begin{abstract}
A distinção mais antiga entre ficção e história, na qual a ficção é concebida como a representação do imaginável e a história como representação do verdadeiro, deve dar lugar ao reconhecimento de que só podemos conhecer o real comparando-o ao imaginável. (...) A meu ver, a história, enquanto disciplina, vai mal anualmente porque perdeu de vista as suas origens na imaginação literária. No empenho de parecer científica e objetiva, ela reprimiu e negou a si própria sua maior fonte de vigor e renovação."12
\end{abstract}

Temos, nesse fragmento, um exemplo claro, dado por um historiador, de superposição, de imbricamento entre o discurso histórico e o ficcional. A história também pode se valer das artimanhas do discurso literário, pois ela também é narração e representação e, assim, não pode ignorar os problemas postos pela condição de um discurso tomado como tal. Problemas esses que giram em torno da linguagem, do sujeito, da memória, etc. Não se trata de assemelhar um discurso ao outro, muito menos de colocá-los em oposição, mas de ver como os dois são capazes de interferir, de afetar, de problematizar um e outro e, sobretudo, de deslocar, de tirar do lugar.

Voltemos a Proteu que descola a verdade e constrói outras histórias. Qual era o tempo de Proteu? Qual escrita? Bom, sabemos de sua astúcia por uma passagem na Odisséia, no canto IV, em que Menelau conta a Telêmaco sobre seu encontro com Idotéia, filha do velho do mar, que lhe revelou os ardis de Proteu, dizendo-lhe o que deveria fazer

\footnotetext{
${ }^{10}$ Historiador americano e professor de Literatura Comparada da Universidade de Stanford.

${ }^{11}$ Historiador americano e professor da Universidade de Cornell desde 1969.

${ }^{12}$ White apud PINTO. Uma memória do mundo, 1998, p. 219. Para um maior aprofundamento entre Borges e história ver esse livro.
} 
para Proteu falar: "qual dos eternos me traz aqui preso e me impede o caminho, e de que modo voltar, navegando o oceano piscoso."13 A Menelau não interessava saber apenas como voltar pra casa, mas também saber quem o prendia ali, e para saber isso, Menelau teve que usar o mesmo ardil de Proteu, "vestir-se"14 de foca para ludibriá-lo. Esse episódio é contado pelas palavras de Menelau que, ao contar, traz a cena pela palavra. A palavra, nesse contexto, presentifica o acontecido, o que é próprio da linguagem épica. Emil Staiger, em Conceitos fundamentais da poética, diz que no gênero épico a narração aparece como uma apresentação, como se, de certa forma, houvesse um distanciamento do narrador com a cena e ele contasse apenas o que visse, num gesto de isenção. O passado toma o lugar do presente pela rememoração do personagem e/ou narrador, o que é possível, porque a palavra traz a coisa ao falar dela. A palavra, no épico, é portadora de um poder "numinoso" 15 quando envolve na sua enunciação o sagrado, pois é concedida pela Memória através das palavras cantadas pelas Musas e a elas evocadas.

Esse era um tempo ainda não dominado pela escrita, ou não contaminado por ela, se pensarmos como Platão, no Fedro, onde ela aparece como pharmakon, remédio ou veneno, que tanto cura como mata. A escrita, nesse contexto, surge sob um paradoxo, num limiar entre o apagamento da memória e/ou permanência dela.

Se Thoth diz que a escrita funcionará para fortalecer a memória, para auxiliá-la, o rei, em contrapartida, diz que a escrita tornará os homens esquecidos, pois não mais lembrarão um assunto por si mesmos, mas por meio de sinais. ${ }^{16}$ E o rei prossegue dizendo: "Em conseqüência, serão desagradáveis companheiros, tornar-se-ão sábios imaginários ao invés de verdadeiros sábios". ${ }^{17}$ Com isso Platão parece dizer que a escrita se afasta da verdade, visto que com o uso da escrita o homem tornar-se-á um sábio imaginário, obterá um conhecimento por imagens, ou com suas palavras, "por meio de sinais". Digo "parece dizer" porque é importante atentar para o fato de como ele diz isso, que método ele utiliza e o que ele prioriza, não somente aqui, mas em seus outros diálogos também. Platão se utiliza do diálogo para difundir sua doutrina, o

\footnotetext{
${ }^{13}$ HOMERO. Odisséia, 2001, p. 85.

${ }^{14}$ Idotéia foi ao fundo do mar pegar 4 peles de focas para que Menelau e seus três companheiros iludissem Proteu, que acabou acreditando que eles eram mesmo as focas de que ele tomava conta.

${ }^{15}$ Termo usado por Jaa Torrano no seu prefácio sobre a Teogonia.

16 Aqui já entra um outro problema para Sócrates que é o da representação. A escrita como sinal já remete à idéia de signo, como "signo de" (expressão usada por Derrida). Como se a escrita fosse uma segunda realidade, ou melhor, se distanciasse do real por uma segunda ordem, como é o nome das coisas.

${ }^{17}$ PLATÃO. Diálogos: Mênon, Banquete e Fedro, s/d, p. 262.
} 
que já deixa claro o valor que ele atribui à oralidade. Ele prioriza a conversa, o diálogo, porque acredita na presença-plena, no fato de que o orador estando ali presente pode explicar qualquer dúvida, qualquer passagem que não tenha ficado clara, e acredita no poder da palavra dita, anunciada. Desse modo, Platão prima a memória em detrimento do esquecimento, pois acredita que toda a formação de um sujeito está atrelada a uma teoria da reminiscência. ${ }^{18}$ É curioso pensar, no entanto, que seus diálogos não trazem o conflito como deveria, o dito não se revela a partir de um contradito, porque, por mais que ele deixe os outros lhe interrogarem, a verdade, a última palavra está sempre com ele.

É interessante notar que, naquela época em que Platão afastava a verdade da escrita, havia uma aproximação muito forte entre memória e imaginação ${ }^{19}$, como observa Paul Ricoeur. Platão considerava a memória como a representação presente de uma coisa ausente. Ora, se a representação pra ele já era um problema, no sentido de que se afastava da verdade, a memória como representação só podia também se afastar da verdade e se aproximar da imaginação. Para Platão, nunca podemos recuperar totalmente o que se passou, o que guardamos do ocorrido é a lembrança dele, o que imprimimos numa cera é o que queremos recordar - sensações, impressões, pensamentos - e o que não imprimimos deixa-se para o esquecimento, desse modo, a recordação de algo que aprendemos não é o que de fato aprendemos. A recordação, segundo Platão, é construída por imagens que, por sua vez, são simulacros, cópias do real, o que significa, para ele, um afastamento ainda maior da verdade.

Dessa forma, Platão, diferentemente de Aristóteles, não concebia nenhuma verdade na poesia; já este diferenciava a poesia da história por aquela tratar de verdades gerais, e esta de fatos particulares, ainda que a história conte o que aconteceu, e a poesia o que poderia ter acontecido. Fala-se sempre dessa verossimilhança que Aristóteles aponta na poesia ${ }^{20}$, mas aqui chamamos atenção para a verdade mesma do discurso poético dentro de seu discurso, ou seja, a poesia, em relação ao real, relata algo de verossímil,

\footnotetext{
${ }^{18}$ PLATÃO. Fédon, 1999.

${ }^{19}$ Giorgio Agamben ao falar da destruição da experiência, em Infância e história, explica como ela está relacionada com a reviravolta do conceito de imaginação, pois na antiguidade ela era o médium por excelência do conhecimento, e hoje é eliminada dele por se dada como irreal. Sobre essa questão ver: (AGAMBEN. "Infância e história: ensaio sobre a destruição da experiência", 2005, p 19-78.)

${ }^{20}$ É desse fragmento, em A poética clássica, que nos referimos: “(...) a Poesia encerra mais filosofia e elevação do que a História; aquela enuncia verdades gerais; esta relata fatos particulares. Enunciar verdades gerais é dizer que espécies de coisas um individuo de natureza tal vem a dizer ou fazer verossímil ou necessariamente; a isso visa a Poesia, ainda quando nomeia personagens. Relatar fatos particulares é contar o que Alcibíades fez ou o que fizeram a ele." (ARISTOTELES. A poética clássica, 1997, p. 28 )
} 
mas dentro dela mesma, relata sua própria verdade. Em todo caso, Aristóteles se refere à palavra verdade para falar da poesia e não da história, talvez por já conhecer as dificuldades em se alcançar a verdade na história.

Nietzsche também não só atribuía a verdade ao discurso literário, mas também a objetividade, qualidades até então muito atreladas à história. Segundo ele,

Pensar a história como objetiva é o trabalho silencioso do dramaturgo, a saber, pensar tudo conectado, tecer esporádico no todo - por toda parte, sob a pressuposição de que uma unidade do plano nas coisas deve ser alcançada, quando ela não estiver presente. Assim o homem estende sua teia sobre o passado e o domestica, assim se expressa seu impulso artístico - mas não o seu impulso para a verdade, para a justiça. Objetividade e justiça não tem nada a ver uma com a outra. Dever-se-ia pensar numa historiografia que não tivesse em si nenhuma gota de verdade empírica comum e que pudesse requisitar o predicado da objetividade no grau mais elevado. $^{21}$

O que Nietzsche condena é aquele homem que busca a verdade como tribunal do mundo, isto é, pensa que o conhecimento da verdade o levará a ser o mais justo dos homens, mas esse ignora que as razões para essa busca não passam de uma caça à glória onde impulsos dos mais diversos: inveja, vaidade, curiosidade, gosto pelo jogo, aparecem. $^{22}$

Nesse texto sobre a utilidade e desvantagem da história para a vida, Nietzsche não detona a questão da verdade, ao contrário, continua acreditando na sua existência, mas de outro modo. Ele até diz que a juventude deve ser educada nos princípios dessa verdade necessária para então dirigir-se a um novo hábito e a uma nova natureza e, quem sabe assim, conseguir alcançar a vida plena e verdadeira. Não se deve mais sustentar no cogito ergo sum, mas no vivo, ergo cogito, pois não é um ser pensante que lhe interessa ser, mas um ser vivente, um ser que vive historicamente, ahistoricamente e supra-historicamente, que busca a história para servir a vida, não para embelezá-la, confortá-la, justificá-la. Por isso, condena também aquele que atrela a objetividade à justiça, que pensa que precisa apenas isentar-se do fato para conseguir olhá-lo com parcialidade, leia-se justiça. A objetividade de grau elevado que Nietzsche propõe é a troca do ameno, da quietude, da parcialidade, para a

\footnotetext{
${ }^{21}$ NIETZSCHE. Segunda consideração intempestiva, 2003, p. 52-53.

${ }^{22}$ Deleuze também condena essa busca pela verdade: "O que quer aquele que diz 'eu quero a verdade'? Ele só quer coagido e forçado. Só a quer sob um império de um encontro, em relação a um determinado signo. Ele quer interpretar, decifrar, traduzir, encontrar o sentido do signo. (...) Procurar a verdade é interpretar, decifrar, explicar, mas esta explicação se confunde com o desenvolvimento do signo em si mesmo.” (DELEUZE apud PINTO, Uma memória do mundo, p. 204)
} 
afetação e a reflexão. Como considerar um discurso de um homem cujo momento do passado que ele descreve não representa absolutamente nada para ele? - pergunta Nietzsche.

É partindo de apontamentos sobre o método benjaminiano e de questões sobre o tratamento da verdade na história e na literatura que invocamos o esquecimento para analisarmos a noção de história. É necessário afirmar que não intencionamos apresentar o esquecimento como um mal ou "um alimento impuro"23, segundo Platão, mas como o instante de interrupção da memória, aquele que se instaura no espaço em branco do lembrar, no momento em que ela "definha / sobre o ontem e as perdidas coisas", quebrando assim o contínuo da narração.

Quebrar esse contínuo é instaurar o "instante de perigo" do qual fala Walter Benjamin, é interromper o curso da história tradicional, contada pelo historicismo, que ignora os obstáculos e as falhas. E o que Benjamin propõe é justamente o reconhecimento desses obstáculos, desses tropeços, dessas fendas, porque reconhecêlos é também aceitar o risco.

O risco é encarar a "imagem dialética" que provoca o "instante de perigo", é fitar a ruína e recolher os destroços, tomá-los para si. ${ }^{24}$ É nessa ruína que o passado se acumula, e enquanto a memória se extenua, o esquecimento aparece como agente, prescinde de seu caráter involuntário, a fim de tecer a memória, destacando umas e descartando outras cenas e imagens num movimento de escolha, já que "cada manhã, ao acordarmos, em geral fracos e apenas semiconscientes, seguramos em nossas mãos apenas algumas franjas da tapeçaria da existência vivida, tal como o esquecimento a teceu para nós",25.

\footnotetext{
${ }^{23}$ PLATÃO. Diálogos. s/d, p. 249.

${ }^{24}$ Essa é uma imagem benjaminiana articulada na tese IX, na qual o autor traça a imagem do anjo da história a partir do quadro de Paul Klee, "Angelus Novus", um anjo de finos traços, cujo olhar não acompanha o resto do corpo e que tem o peso do corpo pendulando para a direção que sopra a tempestade (progresso), enquanto crava seu olhar num tempo atrás (passado), nos escombros amontoados, como se enxergasse ali uma única ruína. "Existe um quadro de Paul Klee intitulado Angelus Novus. Nele está representado um anjo, que parece estar a ponto de afastar-se de algo em que crava o seu olhar. Seus olhos estão arregalados, sua boca está aberta e suas asas estão estiradas. O anjo da história tem de parecer assim. Ele tem o rosto voltado para o passado. Onde uma cadeia de eventos aparece diante de nós, ele enxerga uma única catástrofe, que sem cessar amontoa escombros sobre escombros e os arremessa a seus pés. Ele bem que gostaria de demorar-se, de despertar os mortos e juntar os destroços. Mas do paraíso sopra uma tempestade que se emaranhou em suas asas e é tão forte que o anjo não pode mais fechá-las. Essa tempestade o impele irresistivelmente para o futuro, para o qual dá as costas, enquanto o amontoado de escombros diante dele cresce até o céu". (BENJAMIN apud LÖWY, 2005, p. 87)

${ }^{25}$ BENJAMIN. Magia e técnica, arte e política, 1994, p. 37.
} 
O esquecimento tece a memória, ou o discurso a partir dela, visto que no espaço em branco da sua ausência outro discurso é construído. Desse modo, não interessa contar o que aconteceu, mas contar o que se lembra do acontecido, num movimento de distanciamento do fato para melhor entendê-lo. Benjamin, ao falar de Proust, diz que sua genialidade não está nesse movimento em contar o vivido, mas em contar o lembrado, pois a lembrança "é apenas uma chave para o que veio antes e depois". ${ }^{26}$ Para Proust, o acontecimento vivido é finito, enquanto que o acontecimento lembrado é infinito.

Em as teses "Sobre o conceito de história", Walter Benjamin aponta a idéia de um passado que não encontra no presente sua justificação, sua causalidade. O passado, assim, não é construído apenas de memórias, nem é feito de acúmulos de imagens, mas é interposto pelo presente, por imagens do agora vivido, assim como o presente também é intercedido por imagens do passado. Podemos fazer três perguntas: o que se pode dizer daquilo que foi esquecido? Como contar aquela história que hoje é lembrada apenas como forma, e não como sentido? E qual fim tem a história?

Em outro poema de Borges, de A rosa profunda, ele define a memória como uma forma do esquecimento: “A memória, essa forma de olvido / Que retém o formato, não o sentido, / E que reflete os títulos somente." ${ }^{27}$ A memória tem a forma do esquecimento, é formada pelo esquecimento, por isso, retém o formato e multiplica o sentido. Refletir os títulos somente é resgatar as imagens fulgurantes, é permitir que a história se conte de outro jeito, é, ainda, partir do esquecimento para criar outro presente, outra história, ou ainda acreditar em uma possibilidade de habitar melhor o mundo, pois a felicidade quando não está naquilo que foi vivido, pode ser encontrada na realização do que poderia ter acontecido, na realização de um outro possível. E para isso, há de se resgatar uma imagem do passado para intervir no presente e modificá-lo, modificando, desta forma, também o futuro, já que todo passado está carregado de possibilidades de futuro e não cessa de agir nem sobre um tempo, nem sobre o outro.

É a partir dessa modificação que Benjamin propõe mudar o foco da história, dos opressores e vencedores para os oprimidos e os vencidos, mas isso não seria apenas virar o forro do avesso? Seria inverter sim, seria repetir o gesto dos marxistas, mas Benjamin supera essa inversão ao propor resgatar todo o passado que foi perdido por

\footnotetext{
${ }^{26}$ BENJAMIN. Magia e técnica, arte e política, 1994, p. 37.

${ }^{27}$ BORGES. Obras completas, 1999c, p. 115.
} 
aquela história e aplicar nela o princípio da montagem, "isto é, erguer as grandes construções a partir de elementos minúsculos, recortados com clareza e precisão. E, mesmo descobrir na análise do pequeno momento individual, o cristal do acontecimento total." 28 Os elementos minúsculos, a partir dos quais pode ser descoberto o cristal do acontecimento total, podem ser os farrapos e os resíduos. Retomá-los seria um gesto de fazer-lhes justiça, não por inventariá-los, mas por utilizá-los. Afinal, Benjamin não tem nada a contar, apenas a mostrar, por isso, pode fazer uso das citações sem aspas, dos fragmentos para composição de um texto.

O princípio da montagem está muito presente em seus livros, como Infância em Berlim e Rua de mão única, só para citar dois, e não só por eles serem compostos de fragmentos de situações cotidianas, e muitas vezes sob a experiência de uma criança, mas também, porque é a partir dessas situações habituais e dessas pequenas experiências que é possível entender todo o processo de composição de uma cidade e de uma sociedade.

É dessa forma também que Benjamin propõe uma história mais próxima da que é narrada pelo cronista, imagem articulada na tese III ("Teses sobre o conceito de história"). O cronista é aquele que narra o pequeno, o ínfimo, que por mais que pareça insignificante, não o é para a história. A relativização desses acontecimentos é proposta como uma tentativa de não somente inverter a história, mas de criar outra história. Benjamin sugere que a história seja contada por outro prisma, que sobre aquele fato, ela o interprete de outra maneira. Borges assemelha-se a Benjamin nessa empreitada, pois também reconhece que a história não pode ser feita apenas de fatos heróicos, mas de pequenas coisas que muitas vezes podem nem ser reparadas à primeira mirada, como neste poema, "1982", de Os conjurados: "Um amontoado de pó formou-se no fundo da estante, atrás da fileira de livros. Meus olhos não o vêem. Talvez o amontoado de pó não seja menos útil para a trama que as naus que carregam um império ou que o perfume do nardo" ${ }^{, 29}$ A poeira se forma sob as coisas esquecidas, encobrindo-as com uma fina camada às vezes imperceptível, pois é difícil lembrar daquilo que se esqueceu, é difícil lembrar que ali, naquela estante, entre tantos outros livros, há aquele que pouco se usou, que suas páginas amarelas revelam apenas o tempo que passou e não o quanto os dedos o folhearam.

\footnotetext{
${ }^{28}$ BENJAMIN. Passagens, 2007, p. 503, [N 2,6].

${ }^{29}$ BORGES. Obras completas, 1999c, p. 559.
} 
Discutimos, até aqui, como o questionamento da noção de verdade pode trazer o esquecimento como motor para a construção da história, ou das possíveis histórias. Vimos, também, que ele pode aparecer como agente ou passivo, ainda que insista em apontar para um mesmo objetivo, a redenção. Ele é agente quando age sobre a memória, tecendo-a; e passivo, quando é determinado por ela, quando é preciso esquecer para aliviar seu peso.

O esquecimento do Proteu de Borges é curioso, porque é agente e é voluntário. Proteu quer esquecer, finge esquecer, ignora o que sabe para "entretecer alguns oráculos díspares", porque conhece o peso do saber, é consciente da amargura que carrega por saber sobre o passado, o presente e o futuro.

Nietzsche também aponta o esquecimento como redenção ${ }^{30}$, diz que poderíamos até viver quase sem lembrança, mas seria absolutamente impossível viver sem o esquecimento. $\mathrm{O}$ autor compara o homem ao animal para dizer o quanto o primeiro inveja o segundo que esquece com mais facilidade. $\mathrm{O}$ animal, segundo Nietzsche, vê cada instante morrer e extinguir-se pra sempre, vivendo, assim, a-historicamente, aparecendo sempre e plenamente como o que é. Sem ter nada pra esconder, não pode ser outra coisa senão sincero. O homem, em contrapartida, vive historicamente, pois lembra do que já passou e pode de antemão tentar vislumbrar o que ainda nem aconteceu. Vive imerso no entrechoque dos tempos, passado, presente e futuro. E sofre porque sabe que "a existência é apenas um ininterrupto ter sido, uma coisa que vive de se negar e de se consumir, de se autocontradizer." ${ }^{31}$ Sofre também porque sabe que sua existência é "um imperfectum que nunca pode ser acabado".

\footnotetext{
${ }^{30}$ Faz-se necessário uma nota sobre o esquecimento apontado por Beatriz Sarlo em Paisagens imaginárias. Sarlo não comenta sobre o esquecimento como redenção, mas sobre um tipo de esquecimento que sugere o apagamento dos rastros da história com o intuito de promover uma reconciliação entre passado e presente. Sarlo fala em "moda do esquecimento", algo que foi utilizado pelos governos ditatoriais para apagar seus erros e propor uma reconciliação com a história. No caso da Argentina, Sarlo cita Carlos Menem, ex-presidente da Argentina que governou de 1989 a 1999 e perdoou os ex-ditadores. A autora observa ainda que essa postura proporciona o "igualamento amnésico" da história que é, entre outras coisas, uma afronta ao presente. No Brasil, um exemplo mais recente disso é a decisão de não revisar a lei de anistia. Assim, vale notar aqui uma diferença importante entre o esquecimento redentor e o conciliador. Tanto Nietzsche quanto Benjamin e Borges tratam do esquecimento como redenção, como algo necessário à sobrevivência do próprio sujeito, e não para reconciliar os fatos da história. Benjamin, principalmente, insiste na lembrança dos restos da história. Lembremos da tese III, "nada do que um dia aconteceu pode ser considerado perdido para a história". (BENJAMIN. Magia e técnica, arte e política, 1994, p. 223.) Lembremos também da figura do homem-estojo que contrariamente ao caráter destrutivo "busca sua comodidade, e sua caixa é a síntese desta. O interior da caixa é o rasto revestido de veludo que ele imprimiu no mundo." (BENJAMIN. Rua de mão única, 2000, p. 237.)

${ }^{31}$ NIETZSCHE. Segunda consideração intempestiva, 2003, p. 9.
} 
Para levar tal existência, Nietzsche diz que o homem precisa buscar a felicidade, pois é ela que o mantém preso à vida. E para conseguir tal felicidade é necessário "poderesquecer", isto é, possuir a faculdade de poder sentir o momento vivido, por um instante que seja, a-historicamente, de viver o presente nele mesmo. Para Nietzsche, o homem deve saber medir e dosar o que deve ser esquecido e o que deve ser lembrado, deve saber viver historicamente e a-historicamente, pois são ambos necessários para a saúde de um individuo, de um povo e de uma cultura.

Se voltarmos a pensar sobre o esquecimento em Borges, notaremos a idéia de um esquecimento passivo, diferente do de Proteu, em um poema de A rosa profunda, chamado "Inventário".

\section{Inventário}

É preciso escorar uma escada para subir. Falta-lhe um degrau.

O que podemos procurar no sótão

senão o que amontoa a desordem?

(...)

As vigas do teto estão próximas e o soalho está gasto.

Ninguém se atreve a por os pés.

Há uma cama de vento desconjuntada.

Há umas ferramentas inúteis.

(...)

Há um relógio de tempo imóvel, com pêndulo quebrado.

Há uma moldura desdourada, sem tela.

Há um tabuleiro de papelão e umas peças desparceiradas.

(...)

Há uma fotografia que já pode ser de qualquer um.

Há uma pele rafada que foi de tigre

Há uma chave que perdeu sua porta.

O que podemos procurar no sótão

senão o que amontoa a desordem?

Ao esquecimento, às coisas do esquecimento, acabo de erigir este monumento,

Sem dúvida menos perdurável que o bronze, e que com elas se confunde. ${ }^{32}$

O sótão, que é um pavimento situado abaixo da cobertura do telhado, não é um lugar muito presente na arquitetura de nossas casas, principalmente por conta do clima que não exige das casas um telhado íngreme, de forte declive, para escoar a neve. Assim, a imagem que temos de um sótão é geralmente aquela apresentada nos filmes de países de clima temperado, com as estações do ano definidas.

\footnotetext{
${ }^{32}$ BORGES. Obras completas, 1999c, p. 96.
} 
O sótão do poema parece guardar o próprio esquecimento, pois tudo ali está esquecido, até o próprio lugar que impõe dificuldades para ser alcançado, seja a escada que falta um degrau, seja o soalho que está gasto. É preciso atrever-se a pôr os pés. Os objetos que ali estão contam de quem vive naquela casa que abriga o sótão, falam de seu uso, de seu desgaste: a cama desconjuntada, o relógio quebrado que já não marca o tempo, a moldura que perdeu seu brilho, sua cor, e que nem tela mais sustenta, as peças que perderam seus parceiros, a fotografia apagada pelo tempo, que hoje já não mostra mais quem é, o casaco de pele de tigre que já foi muito usado, a "chave que perdeu sua porta", etc.

Os objetos trazem à tona imagens do passado que foram deixadas para trás, cada um deles pode contar uma história, seja de dor, de amor ou de alegria. Guardar esses objetos como entulho pode não significar um esquecimento total, mas um resguardo, um gesto de descanso da memória. Desfazer-se deles seria um ato mais violento, seria um ato destrutivo, pois se instalaria o espaço em branco, o vazio, o esquecimento. Segundo Benjamin é salutar que esqueçamos para formular um movimento de distanciamento das coisas do passado. Cito Walter Benjamin:

\footnotetext{
Nunca podemos recuperar totalmente o que foi esquecido. E talvez seja bom assim. O choque do resgate do passado seria tão destrutivo que, no exato momento, forçosamente deixaríamos de compreender nossa saudade. Mas é por isso que a compreendemos, e tanto melhor, quanto mais jaz em nós o esquecido. ${ }^{33}$
}

Esse trecho nos leva a pensar em Funes, o memorioso ${ }^{34}$, no quanto sua memória lhe é arruinadora. Funes é aquele que tudo lembra. Um tombo the trouxe um presente intolerável de tão rico e tão nítido. Ele pode recobrar até suas memórias mais antigas com tal precisão, que para lembrar de um dia apenas, gastaria o dia inteiro. Disse Funes, um dia: "Mais recordações tenho eu sozinho que as que tiveram todos os homens desde que o mundo é mundo". 35

Funes tem corpo e mente voltados para o passado, não consegue se libertar dessas imagens que o tomam inteiramente. Podemos pensar aqui até num contraponto: não era Funes que possuía as imagens, não era ele quem as rememorava, mas a própria

\footnotetext{
${ }^{33}$ BENJAMIN. Rua de mão única, 1995, p. 105.

${ }^{34}$ Personagem de Borges de conto homônimo publicado em Artifícios (1994) e nas Obras completas, vol. I.

${ }^{35}$ BORGES. Obras completas, 1999a, p. 125. Esse trecho não seria uma referência a um poema de Baudelaire que diz: "Tenho mais recordações que se tivesse mil anos". (J'ai plus de souvenirs que si j'avais mille ans.). BAUDELAIRE. As flores do mal. p. 292
} 
memória que o ocupava. Como a imagem do anjo de Klee, Funes também não podia juntar os destroços, e não porque o progresso o impedisse, mas porque a memória era tanta, os destroços eram tantos que o encobriam. Ela o paralisa e o sucumbe num quarto escuro, onde a luz não mais lhe permite ver o mundo e, assim, amontoar outras memórias. Funes não consegue pensar, porque não consegue esquecer, e pouco conversa, pois está sempre repetindo o que leu. Esquecer pra ele seria a possibilidade de um espaço vazio, em branco, um instante de sonho. Seria, ainda, uma interrupção da memória, uma quebra de seu contínuo. ${ }^{36}$

Assim, pensar numa possibilidade de contar outras histórias, ou em transformá-las em outros possíveis é, de certa forma, também, acreditar no inesperado, no inevitável. É acreditar não só em outra organização do tempo, mas também no possível dos seus entrecortes, na força de um presente que não é mais fugidio, passagem, mas que é "o agora", em que se faz possível uma guinada de percurso. Sob tal perspectiva, pretendeu-se chegar aqui a uma concepção da história mais espacial e relacional que temporal (no sentido de cronológico, causal), isto é, não mais contar uma história em que se enumeram e ordenam os fatos dentro de uma ordem cronológica, mas reordená-los ao colocá-los em relação, em atrito. Assim pensada, seu fim não seria mais uma justificação, mas uma apresentação para provocar, quem sabe, uma espécie de peripécia aristotélica, uma reviravolta.

\section{Referências}

AGAMBEN, Giorgio. Infância e História: destruição da experiência e origem da história. Trad. Henrique Burigo. Belo Horizonte: Editora UFMG, 2005.

ARISTÓTELES. A poética clássica. Trad. Jaime Bruna. $7^{\mathrm{a}}$ Ed. São Paulo: Cultrix, 1997.

BAUDELAIRE, Charles. As flores do mal. Trad. Ivan Junqueira. Rio de Janeiro: Nova Fronteira, 1985.

\footnotetext{
${ }^{36}$ Nietzsche também tenta imaginar um homem que não possuísse a faculdade de esquecer. Para ele, esse homem não acreditaria mais em si mesmo, pois sempre veria as coisas em estado de mutação, em estado de vir-a-ser. "Pensem no exemplo mais extremo, um homem que não possuísse de modo algum a força de esquecer e que estivesse condenado a ver por toda parte um vir-a-ser: tal homem não acredita mais no seu próprio ser, não acredita mais em si, vê tudo desmanchar-se em pontos móveis e se perde nesta torrente do vir-a-ser: como o leal discípulo de Heráclito, quase não se atrevera mais a levantar o dedo.” NIETZSCHE. Segunda consideração intempestiva, 2003, p. 9.
} 
BENJAMIN, Walter. Rua de mão única. Trad. Rubens Rodrigues Torres Filho e José Carlos Martins Barbosa. $5^{\circ}$ ed. São Paulo: Brasiliense, 1995. 277p.

- Magia e Técnica, Arte e Política: ensaios sobre literatura e história da cultura. Trad. Sérgio Paulo Rouanet. $7^{\text {a }}$ ed. São Paulo: Brasiliense, 1994. 253p.

- Passagens. Trad. Irene Aron e Cleonice Paes Barreto Mourão. Belo

Horizonte: Editora UFMG; São Paulo: Imprensa Oficial do Estado de São Paulo, 2007. $1167 \mathrm{p}$.

BORGES, Jorge Luis. Obras Completas, vol I; vários tradutores. São Paulo: Globo, 1999a.

. Obras Completas, vol II; vários tradutores. São Paulo: Globo, 1999 b.

. Obras Completas, vol III; vários tradutores. São Paulo: Globo, 1999c.

COMMELIN, P. Mitologia grega e romana. Trad. Eduardo Brandão. $2^{\mathrm{a}}$ Ed. São Paulo: Martins Fontes, 1997.

GAGNEBIN, Jeanne Marie. História e Narração em Walter Benjamin. $2^{\mathrm{a}}$ Ed. São Paulo: Perspectiva, 2004.

HOMERO. Odisséia. Trad.: Carlos Alberto Nunes. Rio de Janeiro: Ediouro, 2001.

JENCKES, Kate. Reading Borges after Benjamin: Allegory, afterlife and the writing of history. New York: State University of New York Press, 2007.

LAGES, Susana Kampf. Walter Benjamin: tradução e melancolia. São Paulo: Edusp, 2007.

LÖWY, Michael. Walter Benjamin: aviso de incêndio - Uma leitura das teses "Sobre o conceito de história”. Trad. Wanda Nogueira Caldeira Brant. Tradução das teses: Jeanne Marie Gagnebin e Marcos Lutz Müller. São Paulo: Boitempo, 2005.

NIETZSCHE. Segunda consideração intempestiva: Da utilidade e desvantagem da história para a vida. Trad. Marco Antônio Casanova. Rio de Janeiro: Relume Dumará, 2003.

PLATÃo. Diálogos: Mênon, Banquete e Fedro. Trad: Jorge Peleikat. Rio de Janeiro; Edições de Ouro, s/d.

- Platão - Dialógos: Eutífron ou da religiosidade, Apologia de Sócrates,

Críton ou do dever, Fedon ou da alma. São Paulo: Nova Cultural, 1999.

PINTO, Julio Pimentel. Uma memória do mundo: ficção, memória e história em Jorge Luis Borges. São Paulo: Estação Liberdade; FAPESP, 1998.

SARLO, Beatriz. Paisagens imaginárias. São Paulo: EDUSP, 1997. 
SELIGMAN-SILVA, Márcio (org.). Leituras de Walter Benjamin. $2^{\mathrm{a}}$ Ed. São Paulo: Annablume/FAPESP, 2007.

STAIGER, Emil. Conceitos fundamentais da poética. Trad. Celeste Aída Galeão. Rio de Janeiro: Edições Tempo Brasileiro, 1975.

TORRANO, Jaa. Estudo e tradução. In: HESÍODO. Teogonia: a origem dos deuses. São Paulo: Iluminuras, 1995. 